\title{
Additional Differentiating Characters of the Two Subspecies of Staphylococcus hyicus
}

\author{
By P. E. VARALDO, ${ }^{1 *}$ V. HÁJEK, ${ }^{2}$ P. CANEPARI ${ }^{3}$ AND G. SATTA ${ }^{4}$ \\ ${ }^{\prime}$ Institute of Microbiology, School of Medicine, University of Ancona, Italy \\ ${ }^{2}$ Institute of Microbiology, School of Medicine, Palacký University, Olomouc, Czechoslovakia \\ ${ }^{3}$ Institute of Microbiology, School of Medicine, University of Genoa, Italy \\ ${ }^{4}$ Institute of Microbiology, School of Medicine, University of Cagliari, Italy
}

(Received 31 December 1984)

\begin{abstract}
Forty-five strains of Staphylococcus hyicus subsp. hyicus and 36 strains of S. hyicus subsp. chromogenes were examined for bacteriolytic activity with the same assay system previously used in taxonomic studies on staphylococci. The two subspecies differed from each other chiefly in that for optimal lytic activity $S$. hyicus subsp. hyicus strains required a higher salt concentration in the test medium than $S$. hyicus subsp. chromogenes strains. The lack of lytic activity on B15TP1 medium was a major difference between S. hyicus and $S$. aureus, and the lack of activity on TP2P medium was a major difference between $S$. hyicus and $S$. intermedius. Penicillinbinding proteins (PBPs) were studied in 40 S. hyicus strains. The $S$. hyicus subsp. hyicus strains had only one PBP (mol. wt 79000) while the S. hyicus subsp. chromogenes strains had three distinct PBPs (mol. wts 84000, 82000 and 79000).
\end{abstract}

\section{INTRODUCTION}

Staphylococcus hyicus can be isolated from animals and includes coagulase-positive and coagulase-negative strains. Its role as the causative agent of porcine exudative epidermitis was described by Sompolinsky (1953). Further investigations confirmed its aetiological role in this disease (Jones, 1956; Mebus et al., 1968; Hunter et al., 1970), and implicated it in other infections of pigs (Phillips et al., 1980) and cows (Brown et al., 1967; Devriese \& Derycke, 1979). Proposals for improving or simplifying the isolation and identification of these staphylococci in the veterinary diagnostic laboratory have been made (Devriese, 1977; Phillips \& Kloos, 1981; Maddux \& Koehne, 1982).

Taxonomically, $S$. hyicus has had a complicated history. It was originally described as Micrococcus hyicus (Sompolinsky, 1953), but in 1965 it was transferred to the genus Staphylococcus as Staphylococcus subgroup III (Baird-Parker, 1965). Subsequently, it was reclassified as $S$. epidermidis biotype 2 in the eighth edition of Bergey's Manual of Determinative Bacteriology (Baird-Parker, 1974). Although already in general use in veterinary publications, the name $S$. hyicus was formally proposed by Devriese et al. (1978), who also divided this strain into two subspecies, $S$. hyicus subsp. hyicus and $S$. hyicus subsp. chromogenes. The separation of the two subspecies was made on the basis of a number of phenotypic characteristics and DNA homology studies. Moreover, the known pathogenicity of $S$. hyicus can largely be ascribed to $S$. hyicus subsp. hyicus, whereas the pathogenic relevance of $S$. hyicus subsp. chromogenes is not yet clear.

Bacteriolytic (BA) activity has previously been used as a criterion in the classification of staphylococci of both human (Varaldo \& Satta, 1978; Varaldo et al., 1978a, b) and animal (Varaldo et al. 1978b) origin. The pattern of penicillin-binding proteins (PBPs), which are bacterial plasma membrane proteins that specifically and covalently bind $\beta$-lactam antibiotics,

Abbreviations: BA, bacteriolytic activity; PBP, penicillin-binding protein. 
has been suggested to be a useful marker in staphylococcal taxonomy, and in general bacterial taxonomy (Fontana et al., 1981; Tomasz, 1982; Waxman \& Strominger, 1983). The aim of this study was to investigate a number of strains of the two $S$. hyicus subspecies for BA and PBP patterns.

\section{METHODS}

Bacterial strains. Eighty-one staphylococcal isolates were investigated. Forty-five $S$. hyicus subsp. hyicus strains were isolated from swine: five strains were from Czechoslovakia, twenty-five from Belgium, two (A2869c, S3588) from W. Germany, two (Hunter A and B) from England, two (ZH1029, ZH1037) from Switzerland, and nine from Yugoslavia. Thirty-six $S$. hyicus subsp. chromogenes strains, eighteen each from cattle and swine, were isolated in Belgium. The physiological properties of the strains had previously been investigated by Devriese et al. (1978).

Examination of BA. The BA patterns of the strains were determined with the assay system, composed of eight test media, which was used in previous taxonomic studies on staphylococci (Varaldo \& Satta, 1978; Varaldo et al., $1978 a, b$ ). The BA substrates, the test media, and the BA estimation were as described previously (Varaldo et al., 1978 a; Satta et al., 1980).

Detection of PBPs. The strains to be examined for PBPs were first checked for penicillin-sensitivity using a standard agar diffusion procedure and commercial discs containing 10 units of penicillin $\mathrm{G}$.

The bacteria were grown in brain heart infusion broth (Difco) at $37^{\circ} \mathrm{C}$ on a gyratory water bath shaker (New Brunswick). In late exponential phase the cultures were quickly chilled, and the bacteria were harvested by centrifugation and washed twice with cold $\left(4^{\circ} \mathrm{C}\right) 0.01 \mathrm{M}$-sodium phosphate buffer $(\mathrm{pH} 7 \cdot 2)$. The cells were then resuspended in $10 \mathrm{ml}$ of the same buffer containing $150 \mu \mathrm{g}$ lysostaphin $\mathrm{ml}^{-1}$ (Sigma). After 20 min incubation at $37^{\circ} \mathrm{C}$, unlysed cells were removed by centrifugation at $5000 \mathrm{~g}$ for $10 \mathrm{~min}$ at $4^{\circ} \mathrm{C}$. Membranes were pelleted from the supernatants by centrifugation at $100000 \mathrm{~g}$ for $30 \mathrm{~min}$ at $4^{\circ} \mathrm{C}$, washed twice with the phosphate buffer, and finally resuspended in the buffer at a protein concentration of $20 \mathrm{mg} \mathrm{ml}^{-1}$. If not used immediately for penicillin binding assays, the membranes were stored at $-70^{\circ} \mathrm{C}$ until required.

Samples $(50 \mu 1)$ of membrane preparations were incubated with $10 \mu 1\left[{ }^{14} \mathrm{C}\right]$ penicillin $\mathrm{G}\left[50 \mu \mathrm{Ci} \mathrm{ml}^{-1}\right.$, specific activity $53 \mathrm{mCi} \mathrm{mmol}^{-1}\left(1.96 \mathrm{GBq} \mathrm{mmol}^{-1}\right)$; Amersham] at $37^{\circ} \mathrm{C}$ for $15 \mathrm{~min}$. The reaction was terminated by the addition of $5 \mu \mathrm{l}$ unlabelled penicillin $\mathrm{G}\left(100 \mathrm{mg} \mathrm{ml}^{-1}\right.$ ). Then $25 \mu 10.2 \mathrm{M}$-Tris buffer (pH 6.8) containing $6 \%(\mathrm{w} / \mathrm{v})$ SDS and $6 \%(\mathrm{v} / \mathrm{v}) 2$-mercaptoethanol were added to the samples, which were then boiled for $5 \mathrm{~min}$ in order to solubilize membranes (Satta et al., 1980; Fontana et al., 1983). Electrophoresis was done in $7 \%$ $(\mathrm{w} / \mathrm{v})$ polyacrylamide slab gels containing SDS according to Laemmli (1970). Reagents for SDS-PAGE, including SDS, were from Bio-Rad. For fluorography the gels were soaked in EN ${ }^{3}$ HANCE (New England Nuclear) for $1 \mathrm{~h}$ and then washed in water for $1 \mathrm{~h}$. Gels were dried under vacuum and then exposed to X-ray film (Kodak SO 282) for $30 \mathrm{~d}$ at $-70^{\circ} \mathrm{C}$. PBPs were visualized in the developed films.

Molecular weights of PBPs were determined by co-electrophoresis with protein standards of known molecular weight.

\section{RESULTS}

\section{Bacteriolytic activity}

The BA of the 81 S. hyicus isolates was examined in the eight test media of the assay system. Seven BA patterns were found, four for $S$. hyicus subsp. hyicus and three for S. hyicus subsp. chromogenes. Of the 45 S. hyicus subsp. hyicus strains, 33 had the predominant BA pattern (no. 1 ), and of the $36 S$. hyicus subsp. chromogenes strains, 26 had BA pattern no. 5 (Table 1).

Although the BA patterns of the strains of $S$. hyicus subsp. hyicus and of those of $S$. hyicus subsp. chromogenes were quantitatively different from each other, a certain qualitative similarity was evident. The strains of $S$. hyicus subsp. hyicus usually showed larger zones of transparency on $\mathrm{T} 1$ than on $\mathrm{T} 0$ medium, whereas the strains of $S$. hyicus subsp. chromogenes showed the opposite behaviour. This observation, as well as minor differences between the two subspecies usually observed on T3 and TP2 test media, may reflect the requirement for a higher salt concentration in the medium by $S$. hyicus subsp. hyicus for optimal lytic activity.

The BA patterns of the $S$. hyicus subspecies are shown in Table 2 and compared with those of the two coagulase-positive Staphylococcus species. Some similarities among these BA patterns are obvious. However, the lack of activity on B15TP1 medium was a major difference between $S$. hyicus and $S$. aureus, and the lack of activity on medium TP2P was a major difference between $S$. hyicus and $S$. intermedius. 
Table 1. BA patterns of 45 strains of $S$. hyicus subsp. hyicus and 36 strains of

$S$. hyicus subsp. chromogenes

\begin{tabular}{|c|c|c|c|c|c|c|c|c|c|c|}
\hline \multirow[b]{2}{*}{ Subspecies } & \multirow{2}{*}{$\begin{array}{c}\text { Pattern } \\
\text { no. }\end{array}$} & \multirow{2}{*}{$\begin{array}{l}\text { No. of } \\
\text { strains }\end{array}$} & \multicolumn{8}{|c|}{ BA on the test media: } \\
\hline & & & TP1 & TP2 & TP2P & T0 & T1 & $\mathrm{T} 3$ & $\mathrm{~B} 15 \mathrm{TP} 1$ & a61TP2 \\
\hline \multirow{5}{*}{$\begin{array}{l}\text { S. hyicus } \\
\text { subsp. hyicus }\end{array}$} & & & & & & & & & & \\
\hline & 1 & 33 & ++ & + & - & + & ++ & \pm & - & - \\
\hline & 2 & 7 & + & \pm & - & \pm & + & $\overline{-}$ & - & - \\
\hline & 3 & 3 & ++ & + & - & ++ & ++ & \pm & - & - \\
\hline & 4 & 2 & ++ & + & - & + & ++ & $\overline{-}$ & - & - \\
\hline \multirow{4}{*}{$\begin{array}{l}\text { S. hyicus } \\
\quad \text { subsp. chromogenes }\end{array}$} & & & & & & & & & & \\
\hline & 5 & 26 & ++ & \pm & - & ++ & + & - & - & - \\
\hline & 6 & 8 & ++ & \pm & - & + & + & - & - & - \\
\hline & 7 & 2 & + & \pm & - & + & \pm & - & - & - \\
\hline
\end{tabular}

Table 2. BA patterns of $S$. hyicus and other coagulase-positive species

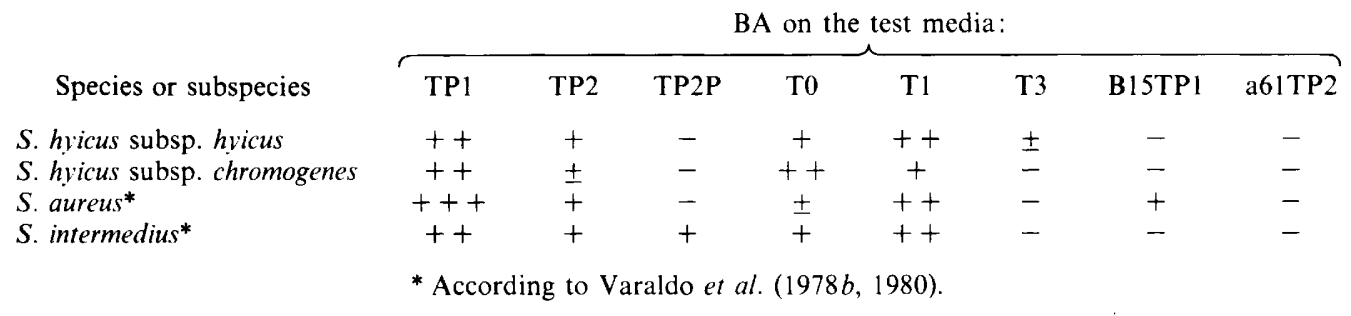

\section{Penicillin-binding proteins}

PBPs were investigated in 20 strains of $S$. hyicus subsp. hyicus and 20 strains of $S$. hyicus subsp. chromogenes. All strains tested displayed zones of inhibition $\geqslant 35 \mathrm{~mm}$ in diameter in disc susceptibility tests for penicillin $\mathrm{G}$.

The PBP patterns were largely uniform within each subspecies. The strains of $S$. hyicus subsp. hyicus had a single PBP with an estimated molecular weight of 79000 . By contrast, the strains of S. hyicus subsp. chromogenes shared a PBP pattern characterized by three distinct bands with molecular weights of 84000,82000 and 79000 . Thus, the single PBP of $S$. hyicus subsp. hyicus seemed to correspond to the lightest PBP of $S$. hyicus subsp. chromogenes. The different PBP patterns in strains of the two subspecies are shown in Fig. 1.

\section{DISCUSSION}

The BA patterns of $S$. hyicus subsp. hyicus and $S$. hyicus subsp. chromogenes are distinctly different from those observed in other staphylococci (Varaldo et al., 1978a, $b ; 1980$ ). The differences observed between the BA patterns of the two $S$. hyicus subspecies, although not marked, are nevertheless well defined in their dependence upon a different optimum salt concentration. It is noteworthy that in previous studies on staphylococcal lytic activity-dealing with both the zones of transparency displayed on solid test media (Satta et al., 1977; Varaldo et $a l ., 1978 a$ ), and the characterization of purified lytic enzymes from different species (Valisena et al., 1982) - the salt concentration proved to be one of the most significant factors affecting BA and helped to discriminate among different, yet related, staphylococcal lytic enzymes.

The different PBP patterns of the two $S$. hyicus subspecies are interesting in many respects. In $S$. aureus, the only staphylococcal species extensively investigated for PBPs, four distinct proteins have been identified, three with high molecular weights and one with a low molecular weight (Kozarich \& Strominger, 1978; Georgopapadakou \& Liu, 1980). No low-molecularweight PBP was found in any of the $S$. hyicus strains examined. The occurrence of only one PBP in $S$. hyicus subsp. hyicus and three PBPs in $S$. hyicus subsp. chromogenes is particularly 


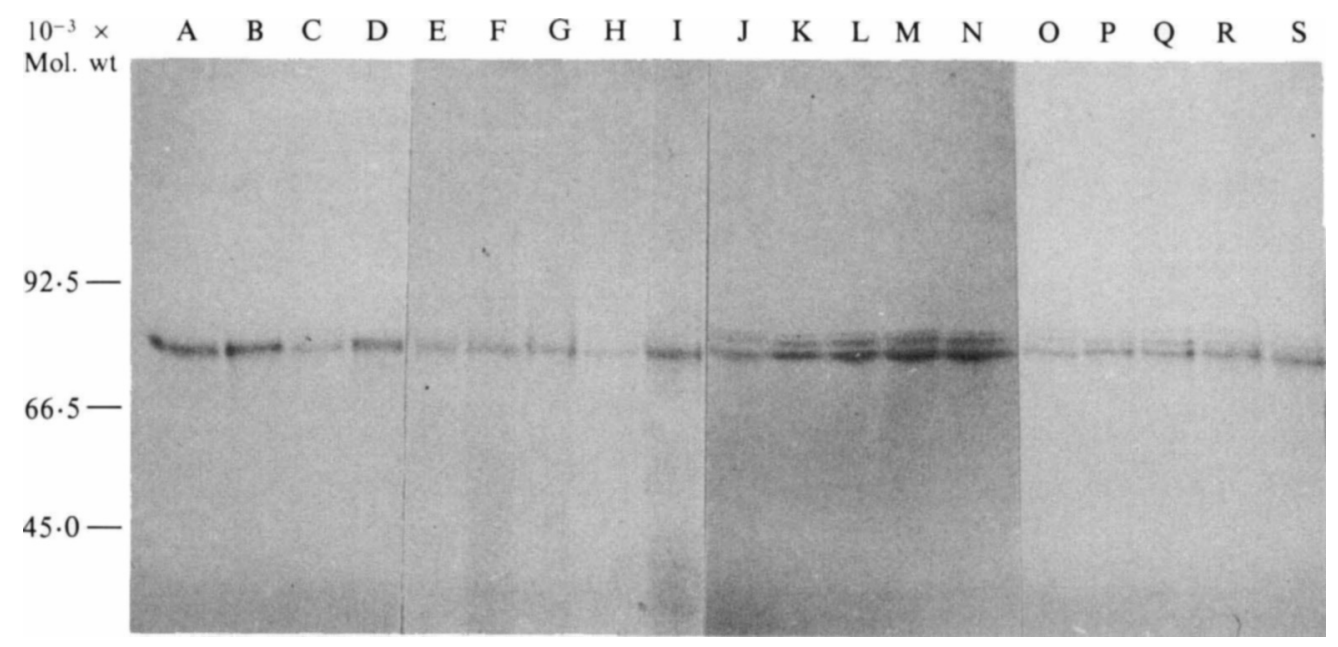

Fig. 1. PBP patterns of nine strains of S. hyicus subsp. hyicus (A through I) and ten strains of S. hyicus subsp. chromogenes (J through S). The strains were: (A) SH66, (B) SH62, (C) SH59, (D) SH50, (E) SH1, (F) SH5, (G) SH 16, (H) SH27, (I) SH 150, (J) SH226, (K) SH225, (L) SH224, (M) SH223, (N) SH221, (O) SH210, (P) SH211, (Q) SH214, (R) SH219, (S) SH220.

significant taxonomically, showing both a difference between the subspecies and pattern uniformity within each subspecies. Taxonomic or phylogenetic relationships might be suggested by the fact that both subspecies share a PBP of molecular weight 79000 . However, a wider investigation in progress in our laboratories shows that in staphylococci, PBPs are most often concentrated within a relatively narrow size range (molecular weight about 80000 ). Preliminary results suggest that the total number of PBPs in staphylococci is unusually low compared with the number in most other bacteria so far examined (Fontana et al., 1981).

The present results contribute to a more consistent biological and taxonomic characterization of both $S$. hyicus subspecies. They differ in several properties including besides the BA and PBP patterns, hyaluronidase and hydrolysis of Tween 80 (Devriese et al., 1978), menaquinone composition (Nahaie et al., 1984), pathogenicity for piglets (Devriese \& Oeding, 1975), and susceptibility to $\mathrm{H}$ phages (Hájek \& Horák, 1981). Moreover, one or more of the following traits are often, but not always, present in only one of the subspecies: coagulase, staphylokinase, pigmentation, and production of acid from maltose, mannitol and turanose under aerobic conditions. The two subspecies also differ in the amount of heat-stable nuclease produced (Devriese et al., 1978). This number of differences between the subspecies raises doubts about the correctness of their taxonomic position. This question was also emphasized by numerical taxonomy which separated the subspecies at $67 \%$ similarity (Hájek \& Schindler, 1981). On the other hand, a DNA-DNA hybridization study of the $S$. hyicus subsp. hyicus and $S$. hyicus subsp. chromogenes strains provided homology values ranging from 30 to $55 \%$, which does indicate a relationship at a subspecies level (Devriese et al., 1978). The solution of this taxonomic problem requires further study.

The authors are greatly indebted to Dr L. A. Devriese (Gent, Belgium) and Dr D. Hajsig (Zagreb, Yugoslavia) for kindly providing the $S$. hyicus strains. Thanks are also due to I. De Mandina for his skilful technical assistance.

This work was partially supported by grants 83.00696 .52 and 84.02042 .52 from the Consiglio Nazionale delle Ricerche.

\section{REFERENCES}

Baird-PARker, A. C. (1965). The classification of staphylococci and micrococci from world-wide sources. Journal of General Microbiology 38, 363387.
Baird-PArker, A. C. (1974). Staphylococcus. In Bergey's Manual of Determinatice Bacteriology, 8 th edn, pp. 483-489. Edited by R. E. Buchanan \& N. E. Gibbons. Baltimore: Williams \& Wilkins. 
Brown, R. W., Sandvik, O., Scherer, R. K. \& Rose, D. L. (1967). Differentiation of strains of Staphylococcus epidermidis isolated from bovine udders. Journal of General Microbiology 47, 273-287.

DEVRIESE, L. A. (1977). Isolation and identification of Staphylococcus hyicus. American Journal of Veterinary Research 38, 787-792.

Devriese, L. A. \& Der ycke, J. (1979). Staphylococcus hyicus in cattle. Research in Veterinary Science $\mathbf{2 6}$, 356-358.

Devriese, L. A. \& Oeding, P. (1975). Coagulase and heat-resistant nuclease producing Staphylococcus epidermidis strains from animals. Journal of Applied Bacteriology 39, 197-207.

Devriese, L. A., Hádek, V., Oeding, P., Meyer, S. A. \& SCHLEIFER, K. H. (1978). Staphylococcus hyicus (Sompolinsky 1953) comb. nov. and Staphylococcus hyicus subsp. chromogenes subsp. nov. International Journal of Systematic Bacteriology 28, 482-490.

Fontana, R., Varaldo, P. E., Canepari, P. \& Satta, G. (1981). Analysis of the penicillin binding proteins in the membranes of staphylococci of different lyogroups (or species). Zentralblatt für Bakteriologie, Mikrobiologie und Hygiene (Abteilung I, Supplement 10), 67-70.

Fontana, R., Canepari, P., Satta, G. \& Coyette, J. (1983). Streptococcus faecium ATCC 9790 penicillinbinding proteins and penicillin sensitivity are heavily influenced by growth conditions: proposal for an indirect mechanism of growth inhibition by $\beta$ lactams. Journal of Bacteriology 154, 916-923.

Georgopapadakou, N. H. \& LiU, F. Y. (1980). Penicillin-binding proteins in bacteria. Antimicrobial Agents and Chemotherapy 18, 148-157.

HáJEK, V. \& HoRÁk, V. (1981). Typing of staphylococci with phages derived from Staphylococcus hyicus. Zentralblatt für Bakteriologie, Mikrobiologie und Hygiene (Abteilung I, Supplement 10), 93-98.

HÁJEK, V. \& SCHINDLER, J. (1981). Cluster analysis of coagulase-positive staphylococci. Zentralblatt für Bakteriologie, Mikrobiologie und Hygiene (Abteilung I, Supplement 10), 27-35.

Hunter, D., TODd, J, N. \& LARKIN, M. (1970). Exudative epidermitis of pigs. The serological identification and distribution of the associated Staphylococcus. British Veterinary Journal 126, 225229.

JoNES, L. D. (1956). Exudative epidermitis of pigs. American Journal of Veterinary Research 17, 179-193.

Kozarich, J. V. \& Strominger, J. L. (1978). A membrane enzyme from Staphylococcus aureus which catalyses transpeptidase, carboxypeptidase, and penicillinase activities. Journal of Biological Chemistry 253, 1272-1278.

LAEMMLI, U. K. (1970). Cleavage of structural proteins during the assembly of the head of bacteriophage T4. Nature, London 227, 680-685.

MADDUX, R. L. \& KoEHNE, G. (1982). Identification of Staphylococcus hyicus with the API Staph Strip. Journal of Clinical Microbiology 15, 984-986.
Mebus, C. A., Underdahl, N. R. \& Twiehaus, M. J. (1968). Exudative epidermitis: pathogenesis and pathology. Pathologia veterinaria 5, 146-163.

Nahaie, M. R., Goodfellow, M., Minnikin, D. E. \& HÁJEK, V. (1984). Polar lipid and isoprenoid quinone composition in the classification of Staphylococcus. Journal of General Microbiology 130, 2427-2437.

Phillips, W. E. \& Kloos, W. E. (1981). Identification of coagulase-positive Staphylococcus intermedius and Staphylococcus hyicus subsp. hyicus isolates from veterinary clinical specimens. Journal of Clinical Microbiology 14, 671-673.

Phillips, W. E., King, R. E. \& Kloos, W. E. (1980). Isolation of Staphylococcus hyicus subsp. hyicus from a pig with septic polyarthritis. American Journal of Veterinary Research 41, 274-276.

Satta, G., Varaldo, P. E., Grazi, G. \& Fontana, R. (1977). Bacteriolytic activity in staphylococci. Infection and Immunity 16, 37-42.

Satta, G., Canepari, P., Botta, G. \& Fontana, R. (1980). Control of cell septation by lateral wall extension in a $\mathrm{pH}$-conditional morphology mutant of Klebsiella pneumoniae. Journal of Bacteriology 142, 43-51.

SoMPOLINSKY, D. (1953). De l'impetigo contagiosa suis et du Micrococcus hyicus n. sp. Schweizerisches Archiv für Thierheilkunde 95, 302-309.

Tomasz, A. (1982). Penicillin-binding proteins in bacteria. Annals of Internal Medicine 96, 502-504.

Valisena, S., Varaldo, P. E. \& Satta, G. (1982). Purification and characterization of three separate bacteriolytic enzymes excreted by Staphylococcus aureus, Staphylococcus simulans, and Staphylococcus saprophyticus. Journal of Bacteriology 151, 636-647.

VARALDo, P. E. \& SatTa, G. (1978). Grouping of staphylococci on the basis of their bacteriolyticactivity patterns: a new approach to the taxonomy of the Micrococcaceae. II. Main characters of 1,054 strains subdivided into "lyogroups". International Journal of Systematic Bacteriology 28, 148-153.

Varaldo, P. E., Satta, G., Grazi, G. \& Romanzi, C. A. $(1978 a)$. Grouping of staphylococci on the basis of their bacteriolytic-activity patterns: a new approach to the taxonomy of the Micrococcaceae. I. Identification of six different "lyogroups". International Journal of Systematic Bacteriology 28, 14I-147.

Varaldo, P. E., Satta, G. \& Hásek, V. (1978b). Taxonomic study of coagulase-positive staphylococci: bacteriolytic activity pattern analysis. International Journal of Systematic Bacteriology 28, 445-448.

Varaldo, P. E., Grazi, G., Soro, O,, Cisani, G. \& SATTA, G. (1980). Simplified lyogroup system, a new method for routine identification of staphylococci: description and comparison with three other methods. Journal of Clinical Microbiology 12, 63-68.

Waxman, D. J. \& Strominger, J. L. (1983). Penicillinbinding proteins and the mechanism of action of $\beta$ lactam antibiotics. Annual Review of Biochemistry $\mathbf{5 2}$, $825-869$. 